While still in his early thirties, Keiller carried out a systematic survey of stone circles and allied monuments in north-east Scotland, making accurate plans and detailed descriptions of each site. A summary account of this work was presented as a paper to the British Association at its Aberdeen meeting in 1934.

In 1925, however, he embarked on the programme of excavation and field-work with which his name will be inseparably associated. He acquired and began excavations on Windmill Hill, near Avebury in north Wiltshire, and continued these annually until 1929 , revealing in detail the first extensive Neolithic settlement to be explored in Britain. The material was housed in a museum in his London house, where it was at the disposal of students, and as a result the earliest Neolithic culture of southern Britain, taking its name from the type-site, was defined and clarified.

From Windmill Hill to the Avebury monuments thernselves was an inevitable step, and in 1933 Keiller began a systematic excavation programme with the examination of the northern part of the West Kennet Avenue, continuing until 1938 within the Great Circle itself. He moved his residence to Avebury Manor, and re-housed his museum within its grounds, making it and the excavated portions of the monument available to the public. He adopted a policy of imaginative but judicious conservation and restoration of the Avebury monuments, and systematically purchased land to preserve these and their surroundings; as a result it was eventually possible for the whole area to be acquired by the National Trust and the Ancient Monuments Department of the Ministry of Works.

Keiller's outstanding contribution to contemporary British archæology was his insistence on high standards of discipline and aceuracy in excavation and field-work, and his realization from the first of the value of scientific techniques as applied to archæological material. He early appreciated the potentialities of air photography, collaborating with Crawford in the "Wessex from the Air" survey, and even discussing with Eckener the possibility of using the Graf Zeppelin for a similar but even more ambitious scheme. At Windmill Hill he insisted on a full study of the faunal and floral remains in their archæological context. But above all it is to Keiller that we owe the inception of the systematic study of British prehistoric stone artefacts by petrographical means, which, following his lead, is now yielding information of the highest importance on manufacture and trade in the early second millennium B.C. Alec Keiller was an enthusiast in the best sense ; full of ideas, stimulating and highly individual. Archæology, like other academic disciplines, can only benefit from the impact of such men. Stuart PiggotT

\section{Dr. E. J. Delporte}

DR. E. J. Delporte, who died at Uccle on October 19, was honorary director of the Royal Observatory at Brussels, where he had continued to work since his retirement from the directorship in 1947.

Eugène Joseph Delporte was born in Brabant in 1882 , and after studying mathematics and physics at the University of Brussels, obtained the degree of D.Sc. with distinction in 1903, entering the Observatory in the same year. In 1923 he took charge of the equatorial instruments and began that programme of minor planet observations which was to become his main interest. It was during this period that Delporte proposed that new boundaries should be adopted for the constellations, defined in terms of hour circles and parallels of declination. 'The proposal was accepted by the International Astronomical Union in 1928, and the work was completed in 1930 . Originally intended to apply only to constellations north of $12 \cdot 5^{\circ}$ south declination, the scheme finally covered the sky from pole to pole, the northern boundaries merging well with those which Gould had previously defined for the southern hemisphere.

In 1936 Delporte was appointed director of the Royal Observatory at Brussels, and pursued a vigorous policy of systematic observations of the minor planets. It is impossible to estimate the number of new discoveries that were made during these years, but some dozens of these minor planets have received permanent numbers. Planet 1247 earries Delporte's name, as does the comet 1941 VII ; but he will probably be best remembered as the discoverer of the two remarkable asteroids Amor (1221) and Adonis, the orbits of which are still exceptional in a list of more than 1,600.

Delporte worked enthusiastically for the International Astronomical Union from its first meeting in Brussels in 1919, and played a prominent part in Commission 20 (minor planets, comets and satellites), of which he was president during 1938-48. He received many decorations from the hands of his countrymen, and was an active member of many scientific societies with astronomical interests. He was a corresponding member of the Bureau des Longitudes and of the Paris Academy of Sciences, and in 1946 was elected an associate of the Royal Astronomical Society.

Conscious always of the needs of his Observatory, Delporte was mainly responsible for the improvements which were effected in 1930 , on the occasion of the centenary of the independence of Belgium, when a 1-metre reflector, a double astrograph and a new meridian circle were added to the equipment. Always ready to praise the scientific success of his colleagues, he gave every encouragement to the younger members of his staff, who will long remember him as a remarkable observer and a wise and friendly counsellor. J. G. Porter

\section{Prof. Robert P. Bigelow}

THE death occurred on September 6 of Prof. Robert P. Bigelow, who retired in 1933 after forty years service in the Biology Department of the Massachusetts Institute of Technology; he was ninety-two years old. A native of Baldwinsville, New York, Dr. Bigelow graduated from Harvard University and received the degree of doctor of philosophy at Johns Hoplkins University before joining the staff of the Massachusetts Institute in 1893 as an instructor. He was appointed assistant professor of zoology and parasitology in 1912, associate professor in 1915, and professor in 1922. Following his retirement, Dr. Bigelow served as honorary lecturer in the Biology Department; and, in 1944, returned as a special lecturer. $\mathrm{He}$ was librarian of the Institute during 1895-1925. Dr. Bigelow was also the former librarian of the Marine Biological Laboratory at Woods Hole, and editor of the American Naturalist and the Technology Quarterly. 